\title{
Peningkatan Kemampuan Mengenal Pola Abc-Abc Melalui Media Gelang Warna Di Kelompok A PAUD Gemsana, Otvai, Alor
}

\author{
Syari'ati Masyithoh \\ PAUD Gemsana, Otvai, Alor, Nusa Tenggara Timur \\ Email: syariati masyithoh@yahoo.com
}

\begin{abstract}
Abstrak
Permasalahan yang muncul pada kelompok A di PAUD Gemsana Otvai, Alor, NTT ialah rendahnya kemampuan anak dalam mengenal pola yang ditandai dengan ketidakmampuan anak dalam memperkirakan urutan berikutnya setelah melihat pola yang berurutan. Oleh karena itu perlu adanya media pembelajaran yang variatif salah satunya ialah dengan media gelang warna. Kegiatan dilakukan secara individual. Observasi dilakukan pada anak kelompok A1 sebanyak 20 anak yang terdiri dari 11 anak perempuan dan 9 anak laki-laki. Objek dalam observasi ini adalah kemampuan kognitif. Metode pengumpulan data yang dilakukan melalui observasi dan dokumentasi. Hasil implementasi menunjukkan bahwa kemampuan mengenal pola $\mathrm{ABC}-\mathrm{ABC}$ dapat meningkat setelah diberikan tindakan dengan menggunakan media gelang warna di kelompok A PAUD Gemsana Otvai, Alor, NTT.
\end{abstract}

Kata kunci: kemampuan mengenal pola $A B C-A B C$, media gelang warna, kelompok $A$.

\section{Abstract}

The problem arose in group A of PAUD Gemsana Otvai, Alor, NTT was the low level of students' capability in recognizing pattern marked by their inability in guessing the next pattern after knowing series of certain pattern. Therefore, various learning media were needed and one of them is the colorful bracelet media. This was used in an individual activity. Observation was done to 20 students of group A1 consisting of 11 girls and 9 boys. Object in the observation was the cognitive skill. The data was collected using observation and documentation. The result of implementation using the media showed that their ability in recognizing $A B C-A B C$ pattern improved after treatment using colorful bracelet media was given to the students of Group A in PAUD Gemsana Otvai, Alor, NTT.

Keywords: recognizing $A B C-A B C$ pattern ability, colorful bracelet media, group A.

\section{PENDAHULUAN}

Pendidikan Anak Usia Dini (PAUD) adalah upaya pembinaan yang ditujukan kepada anak sejak lahir sampai usia enam tahun yang dilakukan melalui pemberian rangsangan pendidikan untuk membantu pertumbuhan dan perkembangan anak agar memiliki kesiapan dalam memasuki pendidikan selanjutnya (Ditjen. PAUDNI, 2011: 2). Adapun ruang lingkup pengembangan pembelajaran Pendidikan Anak Usia Dini (PAUD) dalam Permendiknas nomor 58 tahun 2010 meliputi bidang pengembangan pembentukan perilaku dan bidang pengembangan kemampuan dasar. Bidang pengembangan pembentukan perilaku meliputi nilai agama dan moral serta sosial emosional. Sedangkan pengembangan kemampuan dasar meliputi kemampuan bahasa, kognitif, dan fisik atau motorik yang terlibat dalam pembelajaran jasmani, olahraga dan kesehatan.

Salah satu perkembangan yang penting untuk ditingkatkan dan distimulasi dalam perkembangan anak usia dini adalah perkembangan kognitif. Perkembangan kognitif merupakan kemampuan berfikir dalam memahami konsep-konsep kehidupan anak. Menurut Piaget (Slamet Suyanto: 2005), semua anak memiliki pola 
perkembangan kognitif yang sama dengan melalui empat tahapan, yaitu:

(1) Tahap Sensori-motor

Pada tahap ini anak menggunakan kemampuan inderanya untuk berinteraksi dengan lingkungannya. Lingkungan menjadi salah satu faktor yang penting dalam rangka menstimulasi perkembangan anak pada tahap ini.

(2) Tahap Pra-operasional

Pada tahap ini anak mulai mengenali berbagai simbol dan tanda serta mulai menunjukkan proses berfikir yag lebih jelas daripada tahap sebelumnya. Anak juga sudah mulsi menunjukkan kemampuan untuk melakukan permainan simbolik.

(3) Tahap Kongret-operasional

Pada tahap ini anak sudah dapat berfikir konkret. Anak sudah mulai dapat memecahkan masalah sederhanayang bersifat konkret.

(4) Tahap Formal-operasional

Pada tahap ini anak sudah dapat berfikir secara abstrak, berfikir secara hipotetik dan deduktif, mampu membuat analogi, serta mampu mengevaluasi cara berfikirnya. Anak sudah tidak lagi berfikir pada bendabenda serta kejadian yang terjadi didepan matanya saja, namun pikiran anak sudah muai terbebas dari kejadian langsung.

Perkembangan kognitif anak pra sekolah menurut Syamsu Yusuf dalam masyitoh (2005) antara lain:

a. Mampu berfikir dengan menggunakan simbol-simbol.

b. Cara berfikir anak masih dibatasi oleh persepsi. Cara berfikir anak masih bersifat memusat.

c. Cara berfikir anak masih kaku. d. Anak sudah mulai mengerti dasar-dasar mengelompokan suatu atas dasar satu dimensi, seperti atas kesamaan warna, bentuk, dan ukuran

Adapun ruang lingkup perkembangan kognitif menurut permendiknas No. 58 tahun 2010 terbagi menjadi: 1) Pengetahuan umum dan sains, 2) Konsep bentuk, warna, ukuran, dan pola adalah mengenal pola $\mathrm{AB}-\mathrm{AB}$ dan $\mathrm{ABC}-\mathrm{ABC}$. Indikatornyaialah mengurutkan urutan berikutnya setelah melihat bentuk 2 pola yang berurutan, misal merah, kuning, merah, kuning, dll. Peningkatan kemampuan mengenal pola pada anak usia dini perlu distimulasi. Karena hal tersebut berhubungan dengan pola dapat membantu anak bersosialisasi dan memperluas pengetahuan mereka tentang persamaan serta perbedaan. Pola dapat mengembangkan kemampuan berfikir anak seperti belajar mengamati, mengumpulkan dan mengurutkan. Selain itu pola dapat mengembangkan kemampuan bahasa matematika yaitu saat anak membicarakan tentang penyusunan dan pengamatan (Sujiono, 2014: 115).

Menurut Smith (2009: 141), mengenal pola menjadi modal dasar dalam mengenal konsep dasar Matematika anak tanpa perkecualian pada anak usia dini. Memahami pola menjadi cara bagi anak usia dini untuk mengenali ketertiban dalam mengatur dunia mereka dalam bermain. Kemampuan mengenal pola merupakan bentuk logis dari pemecahan masalah dengan menggunakan media pembelajaran. Menurut Degeng dalam Trianto Ibnu Badar Al- Tabany (2015: 227) media pembelajaran adalah komponen strategi penyampaian yang dapat dimuati pesan yang akan disampaikan kepada si belajar, apakah itu orang, alat, atau bahan. Adapun 
beberapa pengertian media menurut beberapa ahli antara lain:

1. Gagne (1970)

Media pembelajaran adalah berbagai jenis komponen dalam lingkungan anak didik yang dapat memotivasi anak didik untuk terus belajar.

2. Schramm (1997)

Media pembelajaran merupakan teknologi pembawa informasi yang dapat dimanfaatkan untuk proses belajar mengajar.

3. Briggs (1970)

Media pembelajaran adalah sarana fisik untuk menyampaikan materi pelajaran.

4. Gerlach \& ely (1971)

Mengatakan bahwa media apabila dipahamisecara garis besar adalah manusia, materi, atau kejadian yang membangun kondisiyang membuat siswa mampu memperoleh pengetahuan, keterampilan atau sikap.

5. AECT(association of education and communication thechnology,1997)

Memberikan batasan tentang media sebagai bentuk dan saluran yang digunakan untuk menyamapikan pesan atau informasi.

6. Fleming (1987)

Media adalah penyebab atau alat turut menengahi dalam dua pihakatau mendamaikannya.

7. Heinich dan kawan-kawan (1982)

Mengemukakan istilah medium sebagai perantara yang mengatur formasi antara sumberdan penerima, jadi televisi, film, foto, radio, rekaman audio, gambar yang diproyeksikan, bahan0bahan cetakan dan sejenisnya adalah medium.
8. Hamidjojo dalam latuheru (1993)

Media adalah semua bentuk perantara yang digunakan oleh manisa untuk menyampaikan atau menyebarkan ide gagasan, atau pendapat sehingga ide atau pendapat yang dikemukan kan itu sampai kepada merima yang dituju.

Peranan media dalam proses belajar mengajar (Sadiman, 2003) dalam http://profesormakalah.blogspot.co.id/2015 /01/media-pembelajaran.html adalah:

\section{Memperjelas Penyajian Pesan dan Mengurangi Verbalitas}

Sesuai dengan karakteristik dari media, maka penggunaan media dapat membantu manusia mengatasi sedikit banyak keterbatasan indera manusia sehingga pesan yang disampaikan menjadi jelas. Penggunaan media dapat mengurangi verbalitas karena media dapat mendorong anak untuk aktif berperan serta dalam proses belajar mengajar, sehingga informasi yang diterima oleh anak didik tidak hanya dari guru saja tetapi anak didik juga turut aktif mencari dan mendapatkan informasi pembelajaran tersebut.

2. Memperdalam Pemahaman Anak Didik terhadap Materi Pembelajaran

Penggunaan media dalam belajar akan ada kejelasan informasi/pesan tentang materi pelajaran yang diterima anak didik. Di samping itu, melalui media peran aktif anak didik dapat digerakkan untuk memperoleh pengetahuan tentang materi pelajaran, maka hal itu secara otomatis akan memperdalam pemahaman anak didik. 
3. Memperagakan Pengertian yang Abstrak kepada Pengertian yang Koonkret dan Jelas

Materi pembelajaran sering kali adalah sesuatu yang bersifat abstrak. Hal yang abstrak ini tidak mudah dipahami terutama untuk anak usia dini. Oleh karena itu, media mampu menjadikan sesuatu yang bersifat abstrak dapat dipahami secara konkret dan jelas. Misalnya ketika mengajarkan makna kasih sayang, Tuhan, Malaikat, dll.

4. Mengatasi Keterbatasan Ruang, Waktu dan Daya Indera Manusia

Manusia memiliki keterbatasan indera untuk bisa memahami tentang seluk beluk lingkungan kehidupannya jika hanya mengandalkan daya inderanya. Oleh karena itu, manusia membutuhkan bantuan berbagai alat yaitu dengan menggunakan berbagai media. Hal ini sesuai dengan karakteristik media yaitu :

a. Fixative property

Media mampu menangkap, menyimpan dan merekomendasikan suatu objek atau peristiwa yang telah terjadi di masa lampau. Misalnya foto/kamera, film, video, film bingkai, dll.

b. Manipulative property

Media dapat mengubah objek, waktu dan peristiwa menjadi 3 hal: close up (objek yag terlalu kecil terlihat lebih besar:luv, mikroskop,dll), time lapsel high-speed photography (gerak yang terlalu lambat dapat lebih cepat:kamera), dan slow motion (gerak yang terlalu cepat dapat diperlambat:kamera), oobjek yang terlalu besar dapat diperkecil dengan miniatur, gambar, maket,dll c. Distributuve property

Media dapat menyajikan suatu peristiwa dalam radius yang luas seperti gunung berapi, iklim,dll sehingga divisualisasikan dalam bentuk film, dll.

5. Penggunaan Media Pembelajaran yang Tepat akan Dapat Mengatasi Sikap Pasif Anak Didik

Dengan penggunaan media, anak diberi kesempatan untuk bereksperimen, dan bereksplorasi secara luas terhadap media tersebut. Dalam hal ini media pembelajaran berguna untuk :

a. Menimbulkan kegairahan belajar

b. Memungkinkan interaksi yang lebih langsung antara anak didik dengan lingkungan dan kenyataan.

c. Memungkinkan anak didik belajar sendiri-sendiri menurut kemampuan dan minatnya.

6. Mengatasi Sifat Unik pada Setiap Anak Didik yang Diakibatkan oleh Lingkungan yang Berbeda

Setiap anak didik berasal dari lingkungan keluarga yang memiliki budaya, agama, tingkat pendidikan, dan sosial ekonomi yang berbedabeda. Oleh karena itu, setiap anak didik memiliki keunika tersendiri dan berpengaruh terhadap proses belajarmengajar. Dalam hal ini guru dituntuk untuk mengguakan media yang sesuai dengan para anak didiknya. Misalnya guru menggunakan variasi media utuk mengatasi perbedaan gaya belajar para anak didiknya, sehingga media tersebut akan:

a. Memberikan perangsang yang sama.

b. Mempersamakan pengalaman;

c. Menimbulkan persepsi yang sama. 
7. Media Mampu Memberikan Variasi dalam Proses Belajar Mengajar

Dengan menggunakan media yang bervariasi, maka suasana pembelajaranpun akan bervariasi dan menarik bagi anak. Hal ini dikarenakan setiap media memiliki karakteristik yang memungkinkan kegiatan pembelajaran dapat dilakukan dalam berbagai cara dan metode.

8. Memberi Kesempatan pada Anak Didik untuk Mereview Pelajaran yang Diberikan

Dalam proses belajar-mengajar mungkin saja ada beberapa informasi yang terlewat oleh anak. Dengan melihat kembali media yang digunakan oleh guru dalam menerangkan, anak dapat merevisi kembali informasi pelajaran yang pernah diterimanya tersebut.

9. Memperlancar Pelaksanaan Kegiatan Belajar-Mengajar dan Mempermudah Tugas Para Guru

Dengan penggunaan media yang tepat, maka pelaksanaan kegiatan belajar-mengajar akan lebih efektif dan efisien.Dapat dikatakan bahwa salah satu fungsi utama media pembelajaran adalah sebagai alat bantu mengajar. Menurut Hamalik (1986) pemakaian media dalam proses pembelajaran dapat meningkatkan keinginan dan minat yang baru, membangkitkan motivasi dan rangsangan kegiatan belajar, dan juga berpengaruh pada psikologis siswa.

Menurut Levie dan Lentz (1982)

dalam

http://profesormakalah.blogspot.co.id/2015 /01/media-pembelajaran.html

mengemukakan fungsi media pembelajaran sebagai berikut: a) Fungsi atensi yaitu menarik dan mengarahkan perhatian siswa pada isi pelajaran dibantu dengan media gambar sehingga memiliki kemungkinan mengingat isi pelajaran lebih besar.

b) Fungsi afektif yaitu muncul ketika belajar dengan teks yang bergambar, sehingga dapat menggugah emosi dan sikap siswa.

c) Fungsi kognitif yaitu mengungkapkan gambar memperlancar pencapaian tujuan memahami dan mengingat informasi yang terkandung.

d) Fungsi kompensatoris yaitu berfungsi mengakomodasikan siswa yang lemah dan lambat menarima dan memahami isi pelajaran yang disajikan dengan teks.

Menurut Kemp \& Dayton (1985:28) fungsi media pembelajaran meliputi :

a) Memotivasi minat atau tindakan

b) Menyajikan informasi

c) Memberi instruksi

Lorton dalam SetioWargo, kategori media pembelajaran yang dapat digunakan pada anak usia dini terdiri dari tiga tahapan, pertama media manipulatif (media kongkrit), berikutnya media pictorial (semi kongkrit), dan terakhir adalah media symbolic (simbol-simbol).

\section{Media manipulatif}

Media manipulatif adalah segala benda yang dapat dilihat, disentuh, didengar, dirasakan, dan dimanipulasikan. Hal ini menunjukkan bahwa segala sesuatu yang bisa dan biasa ditemukan anak dalam kesehariannya dapat dijadikan media pembelajaran yang lebih kontekstual. Seperti contoh penggunaan kancing, gelas plastik, bola kecil, kaleng, kardus, karet gelang, tutup botol, dan masih banyak lagi. 


\section{Berikutnya adalah media pictorial.}

Dapat diartikan bahwa mediamedia ini adalah ilustrasi dari media yang sebenarnya, biasanya diimplementasikan dalam bentuk gambar-gambar. Alasan yang mendasari penyediaan media-media ini adalah perkembangan pemahaman anak yang mulai memasuki masa transisi dari praoperasional menuju operasional kongkrit.

\section{Media Symbolic}

Tahapan penggunaan media yang terakhir adalah dengan media symbolic. Ini diberikan pada anak yang sudah memiliki tingkat pemahaman yang cukup matang. Media-media ini sudah tidak lagi menggunakan benda-benda ataupun gambar, melainkan dengan rumus-rumus, grafik, ataupun lambang operasional.

Ketiga kategori ini didasarkan pada pemahaman akan keunikan tiap-tiap anak, kebutuhan dan kecepatan anak yang sangat bervariasi dalam menerima pembelajaran. Namun yang terpenting adalah kejelian guru dalam mengikuti prosedur kelayakan sebuah media untuk diberikan kepada anak, yaitu dengan memperhatikan beberapa syarat berikut: (a) Media didisain sesuai dengan perkembangan anak, (b) mudah terjangkau dan ekonomis, atau yang biasa ditemui anak sehari-hari, (c) dapat memberi kesenangan dan aman bagi anak, (d) praktis dan multiguna, satu media dapat digunakan dalam beberapa pengembangan kemampuan, (e) sederhana namun dapat memberikan makna pada anak (Charlesworth:26).

Dari teori tersebut di atas, jelas terlihat bahwa dalam melaksanakan pembelajaran di PAUD, guru perlu menyediakan mediamedia yang manipulatif. Media tersebut sepatutnya disesuaikan dengan tingkat kesiapan atau kematangan anak pada rentang usianya, dapat dimanipulasikan dan bervariasi sehingga menyenangkan dan memberi kepuasan bagi anak. Menyediakan media juga tidak harus dengan biaya yang mahal, guru-guru maupun orangtua dapat memperolehnya dari benda-benda di sekitar lingkungan anak. Meskipun demikian, media harus tetap diperhatikan hiegenitasnya, sehingga tidak membawa penyakit pada anak serta tidak berbahaya bagi mereka. Bukan benda yang tajam, tidak mengandung unsur api, serta tidak beracun. Hal penting lainnya yang perlu diperhatikan dalam meyediakan media-media tersebut adalah bukan hanya tampilan yang menarik yang diutamakan, melainkan kebermaknaan yang dapat diperoleh anak terutama dalam hal peningkatan kemampuan mereka. Dengan menggunakan media pembelajaran yang menyenangkan maka anak dapat belajar sambil bermain.

Anak usia 4-5 tahun berdasarkan Tingkat Pencapaian Perkembangan Kognitifnya dalam Permendiknas No. 58 Tahun 2010 telah mempunyai kemampuan untuk mengenal pola $\mathrm{ABC}-\mathrm{ABC}$ dengan indikator yang akan dikembangkan yaitu mempekirakan urutan berikutnya setelah melihat 3 pola yang berurutan. Kemampuan anak dalam mengenal pola dan menyusun suatu urutan pola sangat penting karena dapat memperluas pengetahuan mereka yang bermula persamaan dan perbedaan yang telah mereka temui. Akan tetapi pada kenyataannya di PAUD Gemsana. Otvai, Alor, NTT masih banyak ditemui anak yang mengalami kesulitan dalam mengenal dan menyusun bola ABC-ABC berdasarkan dengan warna yakni merahkuning-biru, merah-kuning-biru, dll. Adapun implementasinya adalah sebagai berikut: 


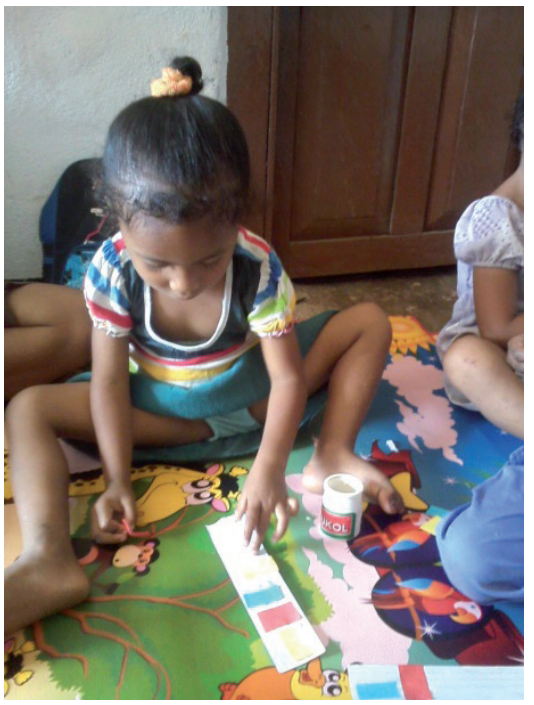

Gambar 1

Anak sedang menempel

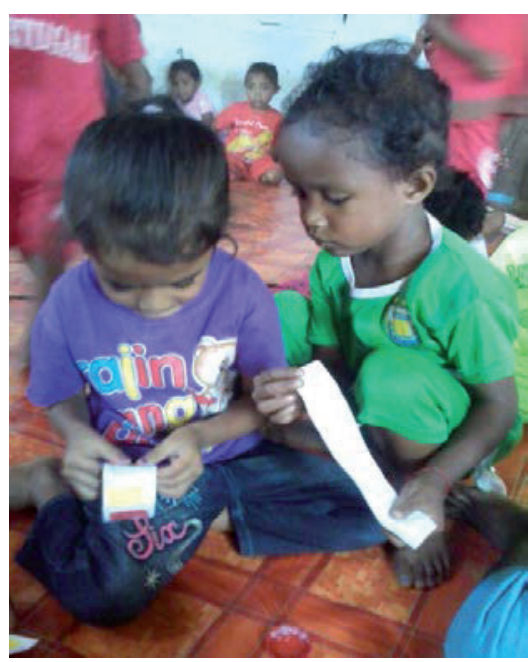

Gambar 2

Anak sedang melipat membetuk gelang

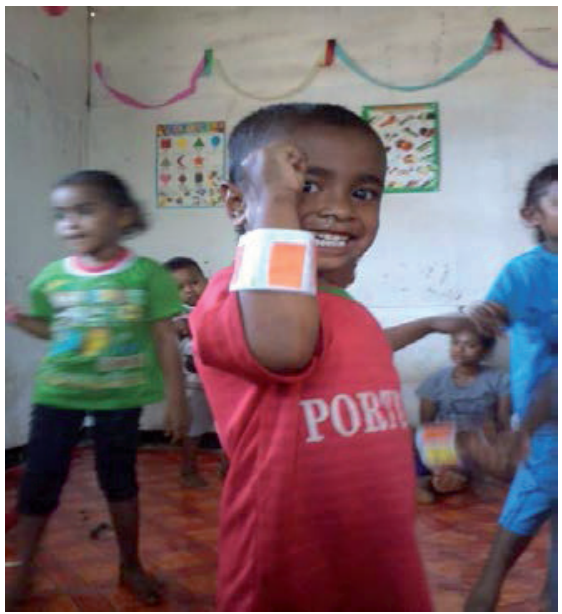

Gambar 3

Hasil karya anak

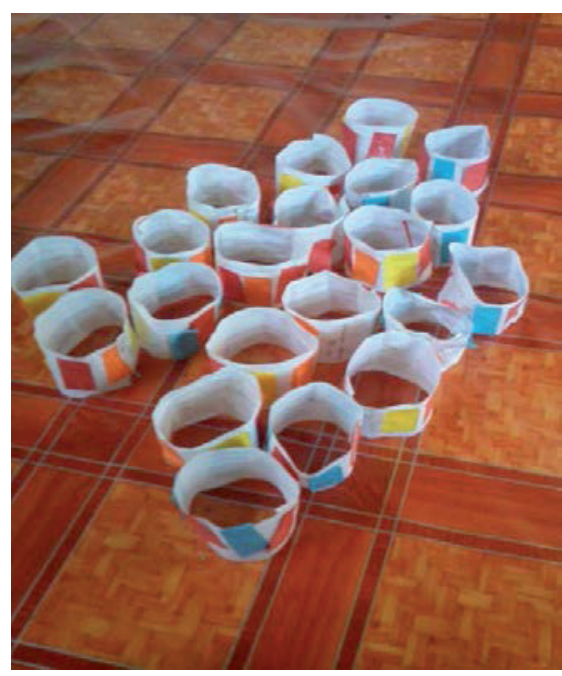

Gambar 4

Hasil karya anak

\section{KESIMPULAN}

Berdasarkan hasil observasi dan implementasi yang dilakukan secara berulang-ulang maka diperoleh kesimpulan bahwa melalui Media Gelang Warna dapat meningkatkan kemampuan kognitif dalam mengenal pola $\mathrm{ABC}-\mathrm{ABC}$ yang berurutan di PAUD Gemsana Otvai, Alor, NTT. 


\section{DAFTAR PUSTAKA}

Slamet Suyanto. (2005). Dasar-Dasar Pendidikan Anak Usia Dini. Yogyakarta: Hikayat.

Masitoh, Ocih Setiasih, \& Heny Djoehani. (2005). Pendekatan Belajar Aktif di Taman Kanak-Kanak. Jakarta: Departemen Pendidikan Kabupaten Nasional. Direktorat Jendral Pendidikan Tinggi, Direktorat Pembinaan Pendidikan Tenaga Kependidikan.

Ibnu Badar, Triono. (2015). Desain Pengembangan Tematik Pembeajaran Tematik. Jakarta: Prenadamedia Group.

Auranet, Priyono. (2015). Diakses dari http://www.academia.edu/6028423/ MEDIA PEMBELAJARAN ANAK USIA_DINI-PPG_UPI pada tanggal 22 Maret 2016 pukul 22.15 WIB

Ekayanti. Diakses dari http://profesormakalah.blogspot.co.id /2015/01/media-pembelajaran.html pada tanggal 22 Maret 2016 pukul 23.07 